\title{
〔W.P.S.J. の紹介
}

\author{
W. P. S. J., 36, No. 1 （1980）目次紹介
}

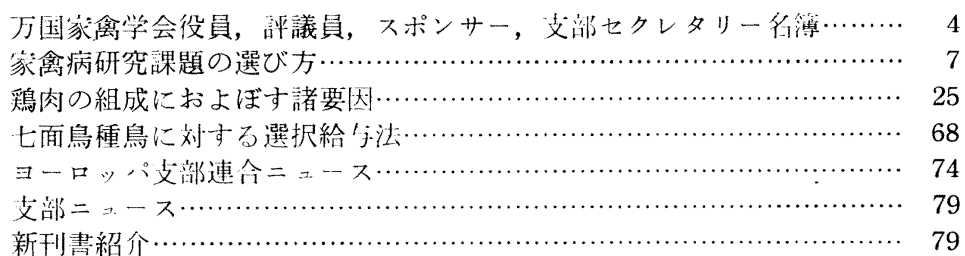

\section{家离病研究課題の選び方}

G. A. Cullen and M. Pattison: World's Poult. Sci. J., 36, 7

この論文は，1979 年10月の英国家禽業会議で行なわ れた講演内容を中心としたもので，英国の国家予算は， どのような仩組と審査学経て各種の家禽病研究に配分さ れるかについて，かなりの紙数定費しているが，それら はわが国の養鷄界とは直接の関係がないので，参考にな ると思われる 3 点を抜粋して紹介する。

1. 重要疾病：合间検讨委員会の家禽部会が 1975 华 に将した第1同邻告で採り上げた疾病ないし淉䞨は下記 のとおりである。

a）收重要：マイコプラズマ症, 商卵低下症候群。

b) 重要：ニューカッスル俪，マレック狱，伝染性父i 管支炎，ガンボロ病，封入体肝炎，コクシジウム症，呼 吸器病，一般的な免疫器的研究。c）普通：伝染性喉靖 父管炎，白血病，ウイルス性関節炎，アデノウイルス， サルモネラ症，卵墜性腹膜炎，壞㾝性度霄炎，脂肪肺・ 腎症候群。腎の病理兴，ストレスに関与する疾病。d）あ

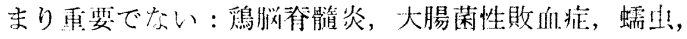
外㑢寄生虫。

2. 研究課題: 現在, 農務省, 農業研究会議义び大学: の閔係㙨関で進行中の研究課題は下記のとおりである。

ニューカッスル病: 病理, 血清反応, ワクチンを含主 総合的研究; ウイルスの構造之細胞病原性; Essex 70 株 を用いたワクチン製造。マレック病：ワクチンの野外弑 験；ウイルス及び関連一ルペスウイルスの抗原性；微細

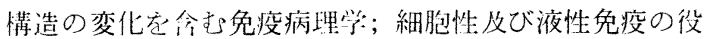
製。白血病：野外貌鳥にけるウイルス分们；ウイルス抗

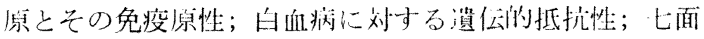
鼠の白血病；トリアデノウイルス：掞原性；淂入体朋炎 の病因と病変; 封入体朋炎とガンボロ病の関倸; EDS-
76 に関する研究。ガンボロ病 : 病原, 病理, 伝播に関す 万研究; 免疫抑制効果; 能動及び受動免疫; 油性ワクチ ンの開発。伝染性気管支炎 : ワクチンによる抗体感応; 診断法の改良; 抗原性の分類; ウイルス分離; マイコプ ラズマとの混合感染。インフルエンザウイルス：ウイル ス学的研究; 野外からのウイルス分離。パラミクンウイ ルス：ユーカイパウイルスなどの各株の性状此較。トリ レオウイルス：ウイルス学的研究; 腱鞘炎の研究。オウ 厶病 : 愛玩鳥及び家禽における診断と血清反応; 細胞培 養による病原体の増殖。マイコプラズマ症：マイコプラ ズーの分離と防压法の研究; 分類の補助手:段になる伴化

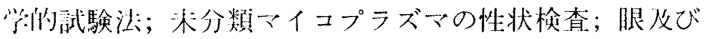

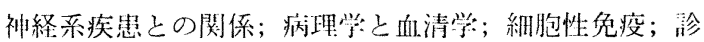
断法; 連続培養法と血清反心の自動化。パスツレラ症： 没学; 各株の病原性，血清型及び各種感作に刘与る抵抗 性; ワクチンの効果。サルモネラ症及び腸内細菌：クー ムステスト索川いた保菌鼠の摘発; サルモネラの保菌と

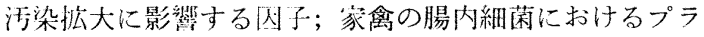
スミド。コクシジゥム症：免疫友岕ないし再感染に刘す る抵抗性；コクシジウムの抁原性の症に開する研究; 非 感染性の出体抗原による免疫の病原性, 特異性及び免疼 原性; コクシジウムの薬剤抵抗性; ブロイラー敷料中の コクシジウムの調榃。代謝病 : 脂肪肝症候群の原刚と病 理発生; 温度感作に上る代謝障害; 菌体毒素による代射 障害; アヒルの代謝病の組織像; 正常及び異常鶏の婜機 能。その他: 呼吸器病ウイルスの免疫; 器官培養を用い た呼吸器病ウイルスの病原性及び抗原性の比較; 呼吸器 病ウイルスと生ワクチンウイルスの相互作用; 鳥類の腸 内ウイルスに関する研究; 酵素抗体法のオウム病, マイ コプラズマ症, アデノウイルス感染症などへの心湖; 疾 病莎の野外調査; 卵管の腫痬; アイソレーターによる起験

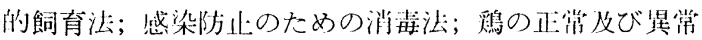
な腎の組織像；正常及びストレス下の鵎の組織像及び白 


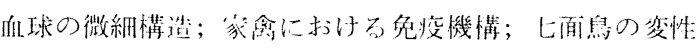
性筋䔀線症。

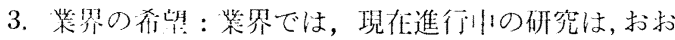
む放满足すべきものであるが，特に下䛉に留堭してほし いという腎思が怙ている。

マイコプラズマ・メレアグリディス：大規杪農垶では 恨絶に呫労しているので, 咕養, 血清学的診断法及び種 卵消毒法老開発されたい。伝染性気管支炎：ウイルスに 多くの血清型があるので, ワクチン効果や血清学的彰断 法に開題が残されている。本病と成䳕の腎臓病との関係 も究明されたい。ガンボロ病：木病により免疫抑制が起 きて他病に罹り易くなったり，また他病ワクチンの効果 が減じたりする。此鵎を油性ワクチンで強力に免疫する よう疼方法を開発されたい。壞瘨性皮虔炎：多くの国 子，例えばガンボロ病，アデノウイルス感染などが複令 して起こると思わ㞦。発生は少ないが，原因究明に 努力されたい。アデノウイルス感染症：封入体肝炎や EDS-76 の他に, 他の因子と複合して呼吸器病, 非特異 的産卵低下，関節炎などを誘発すると思われる。血清型 别ができるような血清診断法の開発や，血清型と病原性 の関倸の笢明をしてほしい。レオウイルス感染症 : ウイ ルスには多くの株があり，株による病原性の差を検討さ れたい。マレック病: 有効なワクチンがあるにもかかわ らず時には多発し，良来よりも高秢で発生する傾问があ る。免疫学的研究及び遺伝的抵抗性の研究を推進してほ しい。白血病: 被害程度ははっきりしないが, かなりの 損害を与えていると思われる。遺伝的抵抗性に関する研 究を推進し，抵抗慆選抜による本病の撲滅が可能かどう かを示されたい。コクシジウム症：薬戍耐性株が出現す るので, 新薬の開発や抵抗性鵎種の作出に努めると其

に，本病の免疫についても追究されたい。脚弱症：一蔀 については原因が判っているが，大蔀分は不明であり， 恐らく栄银, 環境, 遺伝などの影響が大きいと思われる ので, 多方面からの追究が必要である。腎・卵管の障害 : 産卵舀の重要な死闪となっている。原因は恐らく多数 あると思われるが，今のところ研究は進行しておらず, 多方面からの追究が望ましい。海外病 : 現在, 英国の策 禽産業注比較的平穭であるが, 海外からの悪性伝染病, 例えば甚急性ニューカッスル病や七面鳥のアリゾナ感染 症或いはオウム病などが侵入ないし再侵入したら直ちに 対応できるよう, 特に国立研究機関は管に心掛けておい てほしい。

(川上 信)

\section{鶏肉の組成におよぼす諸要因一一総説注}

J. H. Demby and F. E. Cunningham: World's Poult. Sci. J., 36, 25, 1980

\section{I. 鶏肉の栄鉒话}

䳕闪の栄養洒约ついて発表されているデータ在表示し たが，かなりの变動がある。蛋白質は可食部の約 1/4で 过質で消化がよい。チッミン，リボフラビン，ニコチン 酸，ビタミンCなどのビタミンが多く，鉄やリンの食鼠 も多い。

脂肪は大部分が叒下にあり，肉の部分の全量は $1 \sim 2.5$ \%で，低脂肪食品と考元られている。オレイン酸，リ， 一ル酸などの不飽和脂肪酸が多いのが特長である。コレ スラロールは $60 \mathrm{mg} / 100 \mathrm{~g}$ で, 牛, 羊, 豚, 围肉の 70 $\mathrm{mg} / 100 \mathrm{~g}$ より少ない。

炭水化物の含量は少ないが，ブドー糖が大激分で，イ ノシトールがこれにつぐ。

II. 処理中の栄養価の変化

食鳥処理場での処理過程, すなわち, 輸送, 積み下し 之殺, 湯漬け, 脱羽, 水洗, 内臟除去, 検査, 冷涷, 貯 蔵，の過程での変化に関するデータは多くはないが，普 通の処理過程では変化はわずかで，舆視できる場合が多 以。

脱壮の方法について，機械による方法と手洼しりの方 法を比較すると，グリコーゲンの損失の程度が $21 \%$ と 4 \%で，機械のほうが多いという韩笘がある。機械による 方法では，熟による蛋白質の部分的変性がおきている。

冷凍方法には，冷気を用いる乾式法と，水水を用いる 湿式法とがあり，EECで乾式法による製品のみ輸入を 涊めていることから，米国でも乾式法にかわりつつあ る。乾式法では, 水分の減少が著しく, 解涑洔の損失が 少なく，風味を保つ利点がある。湿式法では，阔形分の 1\%にあたる栄養素がし久纱る。

熟成期閑：やわらかい肉にするため死後強㨁が経過し

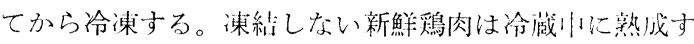
るが，凍絬すると熟成はとまる。強直㫦（と殺後15分以 内), 強㨁中 (间 4 時間後), および強值後（间 24 時间 後）に泠凍した製品について比較すると，強直中の製品 では, 解凍時の損失が多く, 蛋白溶解性が低下し, 料理 による損失も多く，栄養価が低下する。強自後の製品で は, 可溶性窒素分, アミノ酸とペプチド, が最も多い。

凍結乾燥した製思では, 栄養価て差がないが, 熄蔵や くん製では栄養価はおちる。特こくん製では，熱に弱い チァミンは $8 \sim 15 \%$, 有効リジンは 12\%減少したとい う拨告がある。リボフラビンやニコチン酸は比較的安定 である。米国では，塩蔵のときの硝酸湓の添加量を制限 している。牛肉では硝酸塩の影響はないとされている が, 鶏肉ではデータがない。

午詰 : $155^{\circ} \mathrm{C}$ 以上の熱が $2 \sim 3$ 時間かかるので, 蛋白質 の品質が下り，リジンとスレオニンが分解しやすい。ビ 
タミン 10〜30\%減少する。

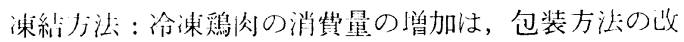
羓, 濑絬方汒の改善, 販売方法の改善によるところが大 きい。凍結方法の主なもの注，嵐による凍結，冷凍板 による凍結，液化ガスによる方法である。液化炭酸ガス に浸漬して $-80^{\circ} \mathrm{C}$ で碀絬する方法が， $-18^{\circ} \mathrm{C}$ 普通の 方法よりよく，一般に緩やかに凍らせるほど，アミノ 酸，ペプチド，㤥酸関連物質の損失が多くなる。冷凍舀 肉では, 蛋白の保水性が減少し, $\mathrm{pH}$ も0.3 程度低下す 子。

カット闪：1壮を 4 つ割などに解体して販売する例が 増えている。これは丸のままに比して料理による損失が 多少増えるようであるが，冷凍品より少ない。

\section{III. 処理後の栄養価の変化}

貝藍：冷蔵すれ湆養価の変化は少ないが，それでも 好ましくない変化をする。これは, フリーザー㷬けとよ ばれる脱水状態で，蛋白質の变性と脂肪の酸化をともな う。気密包装によって防ぐことができた。 $-18^{\circ} \mathrm{Cなら} 60$ 月闒，それより低温ならもっと長く睁蔵できる。子め料 理した上で冷凍した製品がふえている。これでは， -18 ${ }^{\circ} \mathrm{C} て ゙ 2$ 力以内なら風味の低下はない。アミノ酸や脂肪 酸の变化がみられ, その程度は, 料理方法, 賍蔵温度, 期間などにより異なる。

卸詰にして貯蔵する場合にチアミン㑒量を測定したデ 一タによれば，4 力月なら大きな変化はないが，8力月 以上では半減している。あまり医くおかないほうがよ w。

解凍時のドレインによる損失：ドレインとは, 新鮮な

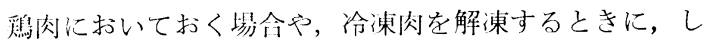
双彇てくる血液状の液体である。種々の栄養素を含んで いるので，これを捨てると損失になる。ドレインの量に は, 種々の惊子が関与する。凍絬するときの速度が速い ほど，また，貯蔵期閏が短いほど少なくなる。解涷方法 によっても珙なり，一般に解凍に装する時闑が产いほど 多くなる。一般にドレイン量が多いほど，溶けている栄 恠素の濃度も商い。

料理による変化：一般に水分がへり，それに忍じて蛋 白, 脂肪, 灰分などが增える。アミノ酸では, リジンと ヒスチジンが熱に弱い。ビタミンでは, ビタミンC， チ アミン，パントテン酸，ピリドキシンは熱に弱い。リボ フラビン, ニコチン酸, ビタミン $\mathrm{B}_{12}$, 葉酸などはかな り安定であり,ビタミン $\mathrm{A}$, ビオチン, コリン, イノシ トールは安定である。

料理の方法によっても，変化の程度は著しく異なる。 (吉时实)

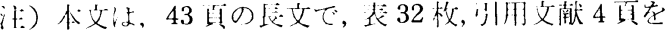

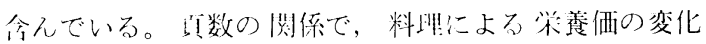
は, 大部分省略した。（抄錄考）

\section{七面鳥種鳥に対する選択給与法}

R. McDonald and G. C. Mmmans World's Poult. Sci. J., 36, 68, 1980

七面鳥の種鳥は，その年齢に忍じて蛋白質含量を減少 した配合飼料を䒜由に与えて飼うことが普通に行なわれ ている。これに刘し，大麦やトウモロコシを与えて，呩 類と配合飼料学選抜させる己とにより，飼料費觉低減す ることが試みられている。本研究では, 款類として小麦 を給与して，成長と産卵におよぼす効果を検討した。

実験には，口ス・スーパーミディ（Ross Supermidi） 種の初生雛, 此 252 羽, 雄 52 羽定用い, 12 週龄まで自 由掑取で育成した後，此隹は単飼ケージに，雄は平飼い舀 舎に移し，2 群に区分した。第 1 群は，28週歯まで，大 すう用ペレット，43週まで種鳥用ペレットを自由に与. え，43〜52 週齢までは，ペレットと小麦とを選択させ た。第 2 群では，43 週涌までは，それぞれのペレットと 小麦を選択させ，43 週歯以後は種鳥用ぺレットのみを 与えた。産卵開始前に 2 可, 産卵期閒中は週 1 回ずつ人 工授精し， 1 週間ごとにふ化試験を行った。

32 週業までの育成期閏的の增体量, 飼料掑取量は, 雄, 雌とも大差のない成績であった。第 2 群の雌では，飼料 掑取量の $46.3 \%$ が麦, 雄では $37.5 \%$ が小麦であった。 産卵期間中の体重変化や飼料摂取量にも，2 群間に大产 がなかった。

$32 \sim 43$ 週齢の産卵第 1 期では，ペレットのみ第 1 群 の産卵率 $36.8 \%$ ，ペレットと小麦を与えた第 2 群は 28.0 \%で，差は統計的に有意であった。飼料の給与法を入れ かえた産卵第 2 期では，ペレットと小麦を与えた第 1 群 $27.2 \%$ ，ペレットのみとした第 2 群 $21.2 \%$ そ,その算は， 危険率を6\%にとると有意である。

ペレットと小麦区とペレットのみの区の受精率は, 89.3\% と $91.0 \%$, 受精卵ふ化率は $66.4 \%$ と 71.0\%であ

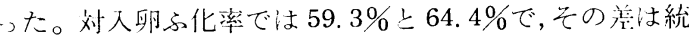
計的に有意であった。

この成績から，小麦を併用して選択給与する方法で は，増体量，飼料掑取量に大差がなく，小麦を食べた分 だけ飼料費が減少した。産卵期になると，育成期の場合 と间様に，飼料提取量の約 4 割を小麦でしめていて，飼 料費は減少したが，産卵率，ふ化率が低下してた。

選択給与する場合の配合飼料の組成などに，今後の検 討を枅する。

（吉田 実） 


\section{W. P. S. J., 36, No. 2 (1980) 〔目次紹介〕}

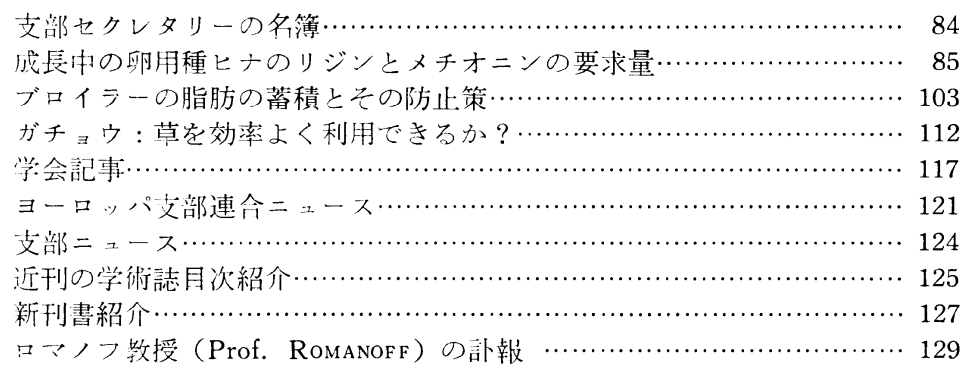

\section{成長中の卵用種ヒナのリジンとメチオニンの要求量}

P. W. WALdroup et al.: W. P.S. J., 36, 85, 1980

ヒナの要求量に関する良来の研究は, 蛋白質の要求量 が主で, アミノ酸についてはあまり重視されなかった。 しかし, 最近の研究成果にもとずいて, 米国 NRCでは 1977 年の改訂版で, リジンと含硫了ミノ酸の要求量を, 6〜14 迭龄の䦌はそれぞれ $0.6 \%$ と $0.5 \% ， 14 〜 20$ 週歯令の 䦌はそれぞれ $0.45 \%$ \% $0.4 \%$ としている。

本研究では，産卵成績におよぼす影響を考虑しながら 卵肋種ヒナのアミノ酸要求量を検討するとともに, 育成 用飼料中の主要な蛋白質源として綿実粕を利用すること 学検討する2つの目的をもって，飼養試験を行なってい る。

実験方法 : 実験には，NRC の要求量を满すように， 6〜14 週歯令用と， $14 \sim 20$ 週龄用の飼料を調整して給与し た。実験 1 では，トウモロコシと大豆粕を主とする飼料 1 と、トウモロコシと綿実粕を主とする 飼料 2 をつく り，これを $2 ： 1$ および $1 ： 2$ の割合で混合して，4種 類の飼料とし，さらに，それぞれに DLーメチオニンと Lーイジン塩酸塩を添加して NRC 標準に合せた 4 種類, 計 8 種類の試験用飼料についてテストした。

実験 2 では, 大豆粕でアミノ酸を添加した飼料 $\mathrm{A}$, 大 豆粕の $1 / 3,2 / 3$ および全量を綿実粕でおきかえ, アミ，

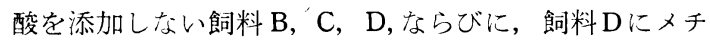
オニンとリジンを添加した飼料 $\mathrm{E} の 5$ 種類の試験用飼料 についてテストした。

綿実粕は，予止抽出法による低ゴシポール粕で，遊離 ゴシポール $0.07 \%$ を含む。飼料 2 およびDのゴシポール 含量は，6〜14 週歯令用で $147 \mathrm{ppm}, 14 \sim 20$ 週歯令用で 78 ppm である。

バブコックの 6 週歯令の此隹ヒナを用い，尖験 1 では40羽 を 1 群とする 2 群ずつをわりあてて 22 週龄まで飼育し,
その後は, 各飼料給与区ごとに, 10 妆を 1 群とする 8 群 に細分し，単飼ケージで，産卵鶏用飼料を与えて 56 日閪 飼育した。

実験 2 では，125 壮を 1 ペンに收谷する平飼いの 20 ペ ンを用意し， 5 箽類の飼料に4ペンずつわりあてて 22 造 齢まで飼育した。その後, 飼育密度の影響を調べる目的 も加味して，各飼料給与区ごとに，30×46 cm のケージ に，1，2および 3 羽ずっ收容する各 5 ケージを 1 群と するそれぞれ 4 群ずつに細分して，336 日間飼育した。

実験結果 : 実験 1 の育成期間の成績では, 綿尖粕主体 でアミノ酸を添加しない区のみが劣っており，この区で は, 性成熟が遅れ, 産卵率, 飼料要求率も劣っていた。 大豆粕の $1 / 3$ を綿実粗でおきかえる区ではアミノ酸添加 の有無にかかわらず，大豆粕区と大差のない成績であっ たが，2/3 以上をおきかえると，産卵成績が劣る傾问が みられた。

実験 2 でも, 大豆粕の $1 / 3$ をおきかえるBでは, 育成， 産卵成績とも，大豆粕のみの $\mathrm{A}$ 区と大差のない成績であ った。2/3 以上をおきかえた CおよびDでは，体重は配 合量に忍じて減少し，飼料摂取量も減少の傾向があっ た。産卵率も低かった。大豆粕全量をおきかえて, アミ ノ酸を添加した Eでは，Dに比し，育成期の飼料摂取量 は変らないが，体重は増加した。ただし，A，Bにはお よばない。産卵成績では，特に改善はされていない。

産卵期における飼育密度の影響は顕著で，1ケージあ たりの将数がふえるほど成績は低下した。なお，この影 響は，育成期の飼料とは無関係であった。

考察：この結果から，飼料中の大豆粕の $2 / 3$ を綿笑粕 でおきかえても，アミノ酸を調整すれ泣，育成，産卵成 績に悪影響はないであろうと推測される。また，低ゴシ ポール綿実粕を育成飼料に唒合しても，産卵成績には悪 い影響はなかった。飼料小のアミノ酸含量から判断し て, 1977 年改言の NRCのアミノ酸要求量は妥当なもの 


\section{ブロイラーの過剩な脂肪の蓄積とその防止策}

C. Y. Lin et al.: World's Poultry Sci. J., 36, 103, 1980

消費者は，腹部 $\rightarrow$ や芰下に過剩に脂肪がついているブ ロイラー肉を好まない。しかし，ブリーダーは，体重や 成黄速度に対する選抜が，過剩な脂肪の蓄積をひきおこ すことは避けがたいことであると考えている。というの は，成長速度と脂肪の蓄積量との問に，正の遺伝相関や 表型相関がみられるので。他方，飼料効率改善への選抜 は，脂肪の蓄積量を少なくするという結果も得られてい るので, 成長速度, 脂肪の蓄積量および飼料効率につい て, 相互の関係をより詳細に研究する必要があろう。

組織学的にみれば，脂肪組織は，脂肪細胞と問質細胞 とからなる。脂肪の蓄積量は，脂肪細胞の数と細胞 1 個 あたりの大きさによって決まる。脂肪細胞は，エネルギ 一源としての不溶性のトリグリセリドを貯閥少る。哺乳 類の場合，このトリグリセリド会成のための脂肪酸は肝 臓や婯腸組織の他，脂肪組織でも合成されるが，トリの 脂肪組織は，脂肪酸を合成する能力が低く，肝臓が脂肪 酸の主要合成臓器である。多くの研究は, 若齢時の脂肪 の増加は，脂肪細胞の数の増加によっているが，成時の 脂肪の增加は，脂肪細胞のサイズが大きくなることによ っていることを示した。

脂肪の蓄積量には, 品種や系統による差が諗められた。 5 品種の総脂質量の比較では, 暗色コーニッシュ種が㷅 も低い値を示したことから，肉量のみを増加させ，屠体 脂肪量を減少させるのに，コーニッシュ種の利用が有益 であることが示された。

脂肪の蓄積は，遺伝的には，通常，ポリジーンによっ て支配されていると考えられているけれども，鵎では， 伴性劣性倭性遺伝子 (dw) が, 同一遺伝子座の正常遺伝 子よりも，より多く脂肪を蓄積することが報告されてい る。このような単一遺伝子による肥満は, ラットやマウ スでも見出されている。

腹部 $\rightarrow$ 脂肪の蓄積量（重量）に刘する遺伝率は $0.3 \sim$ 0.79 と高いので, 脂肪の蓄積量を低くすることは, 選抜 によってい能である。この埸合，成敛速度に影響を! j元 ないで，脂肪量のみを減少させるためには，制限つき選 报指数による育種を行う必装があろう。垷状では，止体 の脂肪量を測定するための確実な方法が開発されていな い難点があるが，脂肪蓄積量の遺伝率が高く，かつ，ブ ロイラーの場令， 世代父代も速いので，光弟検定あるい は，後代検定による選抜も可能であるう。

低蛋白飼料の給与は，蛋白要求量を茜足させようとし
17 巻 5 号 $(1980)$

て, 飼料撰取量が増し，そのために，肥満をひきおこす。 逆に, よくバランスのとれた飼料の給与は, 脂肪の林内 蓄積を少なくする。また, 屠体脂肪の脂肪酸組成注, 飼 料中の脂肪の内谷によって影響されるので, 不飽和脂肪 の給与は, 屠体脂肪中の不飽和脂肪の蓄積を增加させる このことは, ブロイラー肉の品質低下とも関連する。

ケージ飼いと平飼いの比較では，前者の方が脂肪の蓄 積量が多いように思われるが，まだ，確立さされてい ない。

脂肪の蓄積をうながすことなく，最大の笕表を得るた めの至適温度はまだ傕立されていない。

トリは, 年歯の経過とともに, 脂肪の蓄積量が増える。 近年，ブロイラーは，より若龄時に出荷される傾向にあ るので, 年龄的要囦としては, 脂肪蓄積量が低くなる力 向にある。

選抜などの年龄で実施する分によって，脂肪の蓄積量 が異なることがマウスの产験から明らかにされた。この 尖験では，より若い年歯で体重大へ選报した場合，より 遅い年齢で体重大入選抜した埸合に比べて，屠体脂肪量 は増加した。このことから, 脂肪の蓄積量を小さくする ために，より迤い年龄で選抜することが考えら机る。问 様な現象がトリでも久られるか愉討古る必要があうう。

(玉腔 禎紀)

\section{ガチョウ：草を効率よく利用できるか ?}

P. J. Cowan: W. P. S. J., 36, 112; 1980

野生のガンは草を食べるし，芜音化したガチョウは， 昔から放牧している。よい牧草地であれば，速度は遅い が，草だけでガチョウは成長することができる。

ガチョウによる草の消化に関する知識は, 大部分が間 接的なものである。解剖学的な研究から, 筋早の筋肉組 織が，植物の細胞壁を磨砕すると考えられている。

刻んで乾燥したルーサンを与えた消化試験によれば, 乾物の消化率は，ガチョウ $26 \%$, 緬羊 $58 \%$, 粗䋐維の消 化率，ガチョウ $0.8 \%$, 緬羊 $43 \%$, 可溶性炭水化物の消 化率，ガチョウ $57 \%$, 緬羊 $71 \%$ であった。粗蛋白質の消 化率は76\%で，両者閂に大差はなかった。このデータ は, セルロース, 一ミセルロー六の消化能力は, 緬羊の ほうが高いことを示している。飼料の消化管通過速度

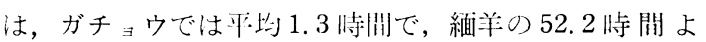
りかなり速い。

ペレット化した乾草・穀類飼料（粗繊維含量 12.5\%） を与える実験では，消化指示物質として寺えた液状のポ

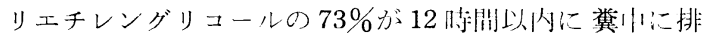
泄され，24 時間で $95 \%$ が排泄された。ポリエチレンチ 一ブを 2 扩よび $5 \mathrm{~mm}$ の底さに切て，粒状の指示物質 
としてケえると，どちらも 3 日間の排泄量は $20 \%$ 以下 で，消化管内に留ることが示された。3日以後に賴中に 排泄される指示物質は，著しくゆがんでいて，大きさや 形状が分らないほどであった。この成績から，ガチョウ では, 飼料粒子の崩壊は微生物の働きょりも, 主として 機械的な作煳よるもので，粒子のかなりの部分が腸よ り前の前胃や筋胃などに残留し，一部は十二指腸より逆 流すると考えられている。

ガチョウの前胃から採取した植物細胞からは，ほぼ完 全に原形質が消失していることが報告され，一方，千 ョウの盲腸には，細胞の大きさをもつ植物性物質は含ま れていない，あるい㴘腸内容物は液状物であると報告 されている。

ガチョウの穓は 4 種類に区分される。第 1 の糞は, よ くかみくだいた草が円筒状になって, 上部に尿酸の結晶 が白くついた䀧で，分解されないままのクロロフィルの 色をしており，消化管内でほとんど变化をうけないまま の草の破片が見受けられる。第 2 の種類は, 濃厚飼料を 与えたときに見られるもので，褐色の瀻維状にみえる物 質からなる少し短い糞である。第 3 と第 4 の種類は, と もに水様で, 盲腸おょび腎臓の排泄物である。 筋肖のグリット川の砂の割合が槀いことから，植物細
胞を磨砕するより，穴をあける働きをすると推測され， ガチョウの粪けの草の形状から，牛のような磨砕作用を しないと考えられている。 $25 \mathrm{~mm}$ の张さの葉は,ごく曾 通にみられ，しかも，ほとんど变化を受けていない。

これらの研究に加えて, 腸内細菌の研究から, セル口 一スの分解はほとんど起きていないし, 細胞内の液状部 分が牧草から抽出されてガチョウの栄養になるとされて いる。ガチョウが食べる各種の植物の「破砕指数」を測 定したデータによれ证，排泄物の 50〜85\%は，葉の片面 のみが完全なままであった。

これらのデータから, 草食性のガチョウの消化機構は, 草食性の哺乳動物のように瀻維の消化を伴うものではな く，スクリュープレス式牧草分画機のように，压搾牧草 とジュースに分画し、ジュースを利用するようになって いると若えられている。したがって，ガチョウの排泄物 は，反楒芜畜の飼料として活用できるものと考兄られて いる。

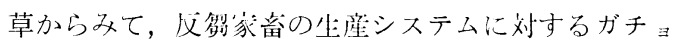
ウの利点は，年間在通じて産卵し，人工授精ができるの で, 製殖能力が高いことであり, 逆に久点は, 草の消化 能力が低いことである。

（吉田 笑）

\section{鶏病研報（J. Japan. Soc. Poult Dis.）第 16 巻（1980 年）目 次}

\section{第 1 号}

《総説》

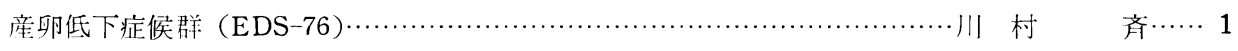

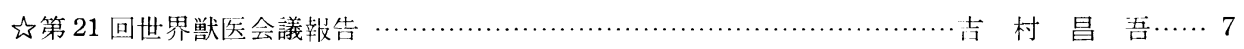

《文献紹介》

オンタリオ州（カナダ）の闪用鷄に見られた塊状肝出血……Gough, A. W. \& Weber, L. J. …113

认第 14 回日米マイコプラズマ会議の概要………………………舀病扣当 USJNR 委員……14

《資料》

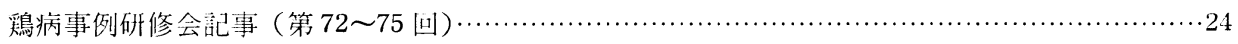

《研究報告》

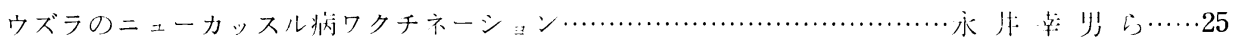

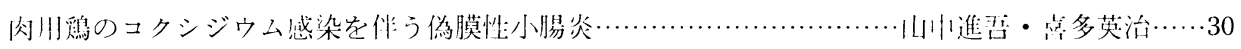

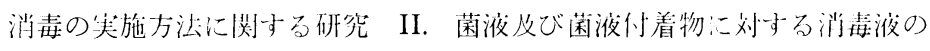

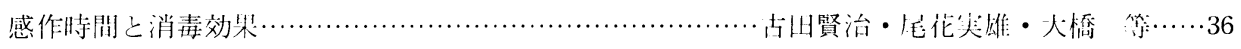

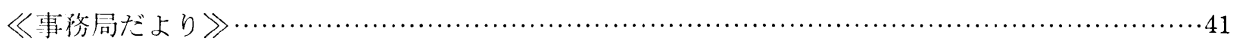

第 2 号

《総説》

ブロイラーのポックリ恼（爹然死婝候群）

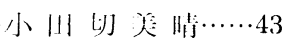

